\title{
Correction to: Higher-moment buffered probability
}

\author{
D. P. Kouri ${ }^{1}$ (D)
}

Published online: 28 March 2019

(C) This is a U.S. government work and not under copyright protection in the U.S.; foreign copyright protection may apply 2019

\section{Correction to: Optimization Letters https://doi.org/10.1007/s11590-018-1359-2}

The original version of this article unfortunately contained a mistake. The copyright line was incorrect. The correct copyright line should be:

This is a U.S. government work and not under copyright protection in the U.S.; foreign copyright protection may apply 2019

Publisher's Note Springer Nature remains neutral with regard to jurisdictional claims in published mapsand institutional affiliations.

The original article can be found online at https://doi.org/10.1007/s11590-018-1359-2.

D. P. Kouri

dpkouri@sandia.gov

1 Optimization and Uncertainty Quantification, Sandia National Laboratories, P.O. Box 5800, MS-1320, Albuquerque, NM 87185-1320, USA 